\title{
International rivalry and global business leadership: an historical perspective
}

Article

Accepted Version

Casson, M. (2020) International rivalry and global business leadership: an historical perspective. Multinational Business Review, 28 (4). pp. 429-446. ISSN 1525-383X doi: https://doi.org/10.1108/MBR-06-2020-0128 Available at https://centaur.reading.ac.uk/91046/

It is advisable to refer to the publisher's version if you intend to cite from the work. See Guidance on citing.

To link to this article DOI: http://dx.doi.org/10.1108/MBR-06-2020-0128

Publisher: Emerald

All outputs in CentAUR are protected by Intellectual Property Rights law, including copyright law. Copyright and IPR is retained by the creators or other copyright holders. Terms and conditions for use of this material are defined in the End User Agreement.

\section{www.reading.ac.uk/centaur}

\section{CentAUR}

Central Archive at the University of Reading

Reading's research outputs online 


\title{
International rivalry and global business leadership: An historical perspective
}

\author{
Mark Casson
}

\section{Abstract}

This paper introduces economic history as a new stream of IB research. It offers a long-term perspective on how international business has evolved over time, focussing on the interplay between multinational enterprise and the nation state. There is rivalry between nation states as well as competition between firms. These two forms of conflict interact. Nations use their leading firms as instruments of international policy, while leading firms rely on political and financial support from home nations. Using historical evidence and cross-country comparisons, the paper explains has the scale and scope in international business activity has changed dramatically over time. (99 words)

Keywords: NATION STATE; MULTINATIONAL ENTERPRISE; INTERNATIONAL BUSINESS; RIVALRY; HISTORY

Word count (text and references): 9954

Address for correspondence:

Mark Casson

Department of Economics

University of Reading

PO Box 218

Whiteknights

Reading, RG6 6AH, UK

E-mail: m.c.casson@ reading.ac.uk 


\section{International rivalry and global business leadership: An historical perspective}

\section{Introduction}

This paper widens the agenda of IB studies by introducing the economic history of IB as a new stream of IB research. The paper demonstrates the advantages of an economic history approach. It addresses 'big picture' issues that often get overlooked when the focus remains sharply on individual firms. This 'long view' of history affords new insights into theory, as it shows how theory-driven forces have operated in the past under unfamiliar conditions. It shows that popular interpretations of IB theory have been somewhat biased by applying the theory mainly to contemporary conditions. This paper shows how theory applies to unfamiliar, but well-documented, conditions in the past.

The first part of the paper outlines the economic history of international business (IB) activity over the past eight hundred years. It shows that the role of the state has been paramount. Its role has been much more significant than that suggested by contemporary IB theory. At key points in history, states have focused on acquiring territory and settling new lands, and not merely on defending their own territories. States have not only established systems of intellectual property rights (IPR) for the benefit of their innovative 'national champion' firms, but have actively sought to undermine the IPR of firms headquartered in rival states by sponsoring industrial espionage.

Foreign direct investment (FDI), this paper shows, was initially used to consolidate trading links, by establishing trading outposts in foreign countries. For aggressive states, such outposts became bridgeheads that were used to colonise the interiors of foreign countries. Land rights, often acquired by force, were then transferred to new settlers from the home country. These rights were then sold on to firms based in the home country. These firms took control of these properties and developed mines, plantations, and manufacturing plants on them. As long-distance transport and communications improved, diverse operations in different countries began to be controlled from the same country. These dispersed operations were consolidated into international business networks, which were precursors of modern multinational enterprises (MNEs).

The second part of the paper considers implications for theory and policy. IB textbooks usually illustrate IB theory by reference to the post-war emergence of the US MNE. IB theory is often introduced, at least implicitly, in terms of the Vernon (1966) product cycle model, in which manufacturing technology developed in the home country is exploited internationally by exporting and then, as volumes increase, by 'market-seeking' FDI. Its successor, the internalisation theory of the MNE, was not, however, simply a generalisation of the Vernon model that includes the licensing decision (Buckley and Casson, 1976; Dunning and Lundan, 2008; Verbeke, 2013). It was a general theory of the MNE which explained all forms of FDI and not just market-seeking FDI. In particular, it encompassed trade-related FDI, as explained in detail below. Extending the historical perspective back to very early times does not, therefore, require new theory. It does, however, require an appreciation of the generality of the theory, and a willingness to include a wider range of phenomena than usual. 
Looking at history through the lens of internalisation theory, it is easy to see that internalisation applies, in principle, not only to the boundaries of the firm but also to the boundaries of the state. From this perspective, an 'empire' is the political analogue of the MNE (Casson, Dark and Gulamhussen, 2009). It is not surprising, therefore, that the firm and the state tend to complement each other. The expansion of empire through 'hard' military power encourages multinational business to follow, and conversely the expansion of multinational business through geographical diversification and market growth spreads empire through 'soft power'.

In the post-war scenario described above the spread of US MNEs led the expansion of the US 'empire'. The US 'empire' was largely a 'soft power' empire, based on an ideology of personal freedom and a culture of conspicuous consumption. In the nineteenth century, by contrast, British military power tended to lead business expansion; 'trade followed the flag'. In the sixteenth and seventeenth century, business expansion led Dutch imperialism, but military power was paramount where Spain and Portugal were concerned.

The balance between business-led and military-led expansion may be changing, however. Post-war Russian attempts to build economic power out of military power failed, but future Chinese attempts to do the same may well succeed. The Russian economy was not sufficiently strong to support its military ambitions, but the Chinese economy is much stronger, and so it may succeed (Kotkin, 2003). State-led business expansion has been characteristic of other 'emerging market economies' too, but as most of these economies are relatively small, and some still relatively under-developed, they do not pose a serious a threat to the contemporary US-led world order.

The paper is structured as follows. Section 2 discusses methodology. It relates the economic history of IB to previous work on business history. Histories of individual MNEs have confirmed the importance of links between FDI and trade. Many contemporary conventional MNEs have their origins in unconventional operations ; e.g. some Japanese manufacturers evolved from trading companies, some food producers were once plantation owners, and some oil companies once prospected on the frontiers of empire. Section 3 presents the core analysis. Key 'lessons of history' are summarised using eight propositions. These propositions identify regularities in the way that international business and international politics have interacted over time. These propositions have important implications for current policy issues, which are discussed in section 4, with an emphasis on the US-China balance of power. Section 5 concludes by considering the implications for future research. It argues that more attention should be paid to the interplay of business, politics and military power.

\section{Methodology}

IB studies tends to concentrate on FDI rather than trade. It is almost impossible, however to separate the history of FDI from the history of trade. FDI developed as a complement to trade, as well as a substitute for it. FDI often led the development of exports; it did not always follow it. Imports as well as exports also play a vital role in the history of FDI. For 
historical reasons, therefore, the scope of this study is wider than in most other studies of FDI.

The same applies to technology transfer. IB studies is mainly interested in technology transfer when it is effected through FDI. Licensing, for example, is often treated as if it were a purely hypothetical alternative to FDI. Technology transfer through industrial espionage or statesponsored talent-hunting is not usually emphasised, except in the HRM and migration literatures (Horton, Kent and Stanton, 2017). Yet historically these are all important mechanisms of technology transfer (Li and Alon, 2020). This study therefore takes a broad view of technology transfer too.

There have been repeated calls for a more historical perspective on FDI (Hertner and Jones, 1986; Lopes, Casson and Jones, 2019). These calls have been answered, in part, by the publication of business histories of leading multinationals (MNEs) (e.g. Ferrier and Bamberg, 1982-2000). The role of economic history remains largely ignored, however. Economic history has a wider scope than business history because it describes the economic and political environment in which MNEs operate; it describes how MNEs respond to this environment, and how the environment responds to the collective impact of MNEs (Baumol, Mokyr and Landes, 2010).

When presenting IB in historical context the scope of the study needs to be broadened. Economic history shows that IB activities regularly interact with domestic activities, so that analysing one without the other is problematic. FDI also needs to be defined in an appropriate way. The modern corporation, with joint-stock ownership and managerial control, is a relatively recent phenomenon. Until the mid-nineteenth century most businesses were partnerships, often between family members, and were on average much smaller than they are today (Wilson, 1995). Yet many of these early businesses employed people abroad, or owned property abroad, as explained below. These foreign assets are regarded in this paper as early forms of FDI.

Early IB research had a strong US orientation, as noted above. The origins of IB, however, can be found well before the US existed. Brazil, for example, was an important destination of Portuguese FDI in the sugar industry by the sixteenth century (Lockhart and Schwartz, 1983). Removing the US-European bias is not only necessary for historical purposes; it also makes it possible to present established theory in a more balanced way.

\section{Strategic aspects of FDI in a long-run global context}

This paper is not structured as a conventional historical narrative. If it were, it would appear as a chronology of events, organised by period, with potentially abrupt, but somewhat artificial, transitions between one period and the next. The emphasis would be on the citation of sources, allowing the reader to validate every statement using a reliable authority (Casson, 2019). Additional points have been derived from Casson and Casson (2013), Lopes, Casson and Jones (2019), Dunning (1983) and Jones, G. (2002, 2005). These books and papers cite numerous sources for the both the business history and the economic history of IB. 
International competition involving firms and nations has been studied by many scholars, but most notably by Jones, E. (2003) and, more recently, Bernholz and Vaubel (2004)

The specific contribution to theory made in this paper comprises the eight key propositions set out in section 3. Each proposition is derived from historical evidence, and translates historical insight into a simple theoretical point. All the propositions are compatible with standard IB theory. Some are already very familiar; in these cases history confirms the longrun validity of the theory. Other points are not so familiar. They reveal new insights regarding the interaction of firm and state. They show that the full implications of theory are best appreciated by examining how theory works under a wide variety of different historical conditions.

The period of the study is as long as sources permit, and the geographical scope at any time is as wide as these sources permit. The survival of written sources is the major limitation of the study (Lewis and Moore, 1999). The study begins c.1200 and runs continuously for eight hundred years down to the present day. The geographical scope encompasses Western Europe and its colonies (i.e. North and South America, Africa and Australia). Early information on Asia and the Middle East is also available, but is more limited. Information on China is very limited owing to the loss of early records.

\section{Proposition 1. International trade stimulates FDI}

From a historical perspective the origins of FDI are closely connected with the development of long-distance trade. Continuous records of organised trade in Western Europe go back to c.1250. They show that trade was organised by individual merchants, who often collaborated with other merchants, who might be family relatives, or members of the same club, association, or guild. Trade was often initiated by a merchant in the exporting country, but the need for return cargoes to cover transport costs encouraged exporting and importing to be linked (Dollinger, 1970).

The development of regular trade on long-distance routes often benefitted from having a permanent representative in the foreign port. The representative could distribute the exports to local customers, and buy up goods from local suppliers ready for the return voyage. It was therefore useful to own a warehouse at the port for the storage of goods, namely exports from the home country awaiting local distribution and imports to the home country awaiting shipment.

A permanent representative was sometimes an independent agent and sometimes an employee (Cools, Keblurek and Nolaus, 2006). The independent agent had an arm's length relationship with the merchant, and they worked on commission or for a fixed fee. The employee, however, was internal to the mercantile enterprise and therefore represented an early form of FDI.

The warehouse could be rented by the home merchant, or owned by them, or it could be rented or owned by their independent representative instead. So long as the merchant either employed their representative or owned their warehouse there was some form of FDI. If the 
local representative was a business partner of the home-country merchant then an international joint venture was involved.

Early arrangements of this kind did not normally involve a joint stock firm, as indicated above. The closest analogues of the modern corporation were chartered trading companies, and some highly-organised urban guilds. Many arrangements involved partnerships between friends and relatives; sole traders were uncommon because of the large amount of capital, and the high degree of risk, involved.

Trade also needed to be financed, and international trade required currency exchange. Merchants attending international fairs found it risky to carry large amounts of currency on their person and this created a demand for international branch banking involving the clearance of debts between different accounts held at same bank. The branch banking system organised by the Italian 'supercompanies', such as the Medici Bank, represented another form of trade-related FDI (Hunt, 1994)

Trade and FDI were therefore complementary from an early date. They remain complementary today. Major exporters often access a foreign market through a sales subsidiary. This subsidiary may own or rent a warehouse, and employ various workers, including delivery drivers and sales staff. Sales subsidiaries may have considerable autonomy in the way they organise logistics, but little autonomy in the way in which they manage and protect the brand.

So why are exports and FDI so often regarded as substitutes in modern IB? While IB theory recognises that trade and FDI may be complements in resource-seeking FDI, it tends to emphasise market-seeking FDI instead. The emphasis on substitution arises because the theory of market-seeking FDI focuses on the location of production rather than the location of distribution (Buckley and Casson, 1998). Location of production at home (exporting) is a direct substitute for location of production abroad (FDI). Location of distribution is not regarded as an issue in simple statements of the theory because it is assumed to be always local. But this leaves open the question of whether distribution is locally owned or not. Simple expositions of IB theory implicitly assume that it is independently owned. This can be deduced from the fact that in simple statements of the theory FDI is never associated with exporting.

In practice, however, there are strong grounds for internalising distribution. Some of these reasons applied in the distant past: namely better inventory management and quality control. These reasons have been reinforced in recent times by the need to manage and protect the reputation of international brands (Lopes, 2007). Statistical evidence from company data shows that major exporters routinely establish sales subsidiaries in destination counties; however, these subsidiaries are often run from small offices, and as there is often no production plant associated with them they are omitted from any census of production (UK government, 2020).

Proposition 2. The flow of FDI is mainly from a rich and powerful country to a weaker one. 
From a historical perspective the direction of FDI has been typically from a rich and powerful country to a poorer and less-powerful one. Modern IB theory suggests that 'powerful' means ownership of a superior proprietary technology, or some other intangible asset such as a strong brand (Verbeke, 2013; Casson, 2018). History suggests a somewhat broader and more tangible view of power, however. It has often meant military power (Kennedy, 1987; Strange, 1988).

Consider two countries, one of which has superior military power. There are opportunities for trade; for example, one country (the 'upstream' country) may have significant endowments of raw materials while the other (the 'downstream' country) has the skills to transform the raw materials into finished product. Some of the product can be exported back to the rawmaterials provider as payment for the raw materials. This is typical of colonialism, from the rise of the Spanish Empire in the sixteenth-century to the decline of the British Empire in the first half of the twentieth century (Pedler, 1974).

Suppose to begin with that the downstream country has superior military power. They may threaten to attack the upstream country unless they are given favourable terms of trade. They may prefer, however, to consolidate their power by invading the upstream country and taking possession of the raw materials. This was a practice in the sixteenth and seventeenth centuries and was typically a two-stage process. In the first stage the upstream country was conquered and a colonial government or local 'puppet dictator' was put in control. The new government then reformed property ownership. Common property was 'privatised' and concentrated in the hands of a local elite. Ordinary people might be allowed to retain a smallholding attached to their house. In the second stage the local elite sold some of their extensive lands to foreign investors from the powerful country. Foreign investors were mainly interested in the most valuable land where key raw materials were located. These were acquired by firms headquartered in the more powerful country. Many of these firms have been described as 'free-standing', because all their tangible assets were located outside their home country (Wilkins and Schroter, 1998). FDI in such countries was therefore mediated by a process of colonisation in which property in the occupied country was turned into a saleable commodity before being acquired by foreign firms.

History demonstrates numerous variants on this theme. In some cases the population of the occupied country was enslaved; they become servants of the local elites, or, in a worst-case scenario, were sent as forced labour to work on plantations or in mines. Slavery was prominent in the sugar trade of the West Indies and in the American cotton trade before the Civil War (Beckert, 2014; Olmstead and Rhode, 2018; Williams, 1966) .

In other cases the occupier imposed a meritocratic system of personal advancement in which native-born individuals deemed to be most able or most compliant were appointed to responsible jobs, and only those deemed less able were required to carry out menial work. This was characteristic of the late-nineteenth-century British administration of India (Mukhopadyay, 2018). 
In other cases the raw-material rich country may possess the military power. This case generates a rather different form of FDI. It may involve off-shoring the final stages of manufacturing, e.g. sewing clothing and apparel, or off-shoring low-skilled jobs in general, such as packaging and assembly. The UK off-shored penal servitude in the early nineteenth century, and waste disposal in the twentieth century.

Cheap labour can be imported into the powerful country to act as factory workers, household servants or to provide basic public services. This labour may be recruited from the less accessible areas of the weaker country where employment opportunities are scarce. Examples include the US FDI in Mexico and Cuba, and UK FDI in the West Indies (Ramirez, 2006: Williams, 1966) .

Proposition 3. A rich and powerful country is normally technologically advanced

The origins of military superiority often lie in superior technology. Since the dawn of history political leaders have sought military advantages by promoting innovations in military technology. Historical examples include innovations in equipment, such as armour; firepower, such as explosives; construction, such as fortresses and castles; and organisation, such as systems of command and control (Rogers, 2010).

Political and military leaders have long recognised the importance of attracting talented inventors who could promote new technologies of this kind (Cunningham, 1897). They targeted specific groups of foreign migrants who they believed possessed valuable knowledge. They offered bounties to talented foreign migrants, and in some cases encouraged them to bring their associates (e.g. their apprentices) with them. In the fifteenth and sixteenth centuries, for example, English monarchs targeted talented metal-workers and cloth-workers in continental European countries in which there was political and religious unrest (Luu, 2005; Ormrod, McDonald and Taylor, 2018).

It was also possible to send people abroad as spies. They could pose as diplomats or as wealthy foreign tourists. Espionage was so important in obtaining secret military technologies that in the seventeenth and eighteenth centuries, for example, much European diplomacy was conducted on the assumption that foreign spies were everywhere (Schaffer, 1995).

Historical evidence clearly indicates that the political and military elites of leading countries did not normally take endowments of technological knowledge as given. The state of technological knowledge was something they believed that they could control (Cunningham, 1897). In modern terminology, they did not think in terms of Ricardian comparative advantage, where resource endowments are given, but rather in terms of absolute advantage, where resource endowments are created or acquired. They pursued absolute advantage derived from superior technology.

Unlike modern advocates of absolute advantage, however, these elites did not see research as the main way forward. The pursuit of absolute advantage was perceived, again in modern terminology, as a 'zero sum game'. Technology was to be stolen from rival countries. Technology as not conceived as a 'public good' that could profitably be shared between 
countries. Technology was regarded instead as a 'private good'; it was in the heads and the hands of talented people that leaders sought to recruit.

Military superiority demanded absolute advantage. Technology was to be stolen, thereby depriving the loser of the technology they once had. As talented people migrated, the weaker country would lose capability as the stronger country gained it, and the limit to this was reached only when the weaker country's capability was completely wiped out. Such 'technological warfare' characterised relations between leading economic powers for centuries. In the Second World, for example, the military superiority of the Allied Forces relied heavily on the ingenuity of talented German emigrants to the UK and the US, and in the ensuing 'Cold War', Russian intelligence recruited British and US intellectuals as spies (Fialka, 1997)

This emphasis on technological advantage accords well with modern IB theory. Many contemporary critics of comparative advantage theory reject its implications for the very reasons given above. They emphasise the absolute advantage of superior technology instead. Comparative advantage theory remains correct, of course, but only on the assumption that technology and resources are given, and cannot therefore be changed. Relaxing this assumption changes the policy implications in a dramatic way (Narula, 2003).

There remains an important difference from modern IB theory, however. Before the late nineteenth century, there was little formal recognition of intellectual property rights (IPR), and patent rights were very expensive to acquire and police (Fitton, 1989). Inventors received social recognition, as did other original thinkers such as authors and composers, but copyright was either non-existent or difficult to enforce. The main exception concerns state monopolies awarded to private entrepreneurs. In Europe in the seventeenth and eighteenth centuries, 'promoters' or 'undertakers' purchased licenses monopolies to exploit new discoveries from the state. But these monopolies were authorised mainly to raise public revenue; promoting innovation and benefiting the public were usually secondary considerations (Yamamoto, 2018). These licenses (or 'charters') were very differences from the licences of today.

The lack of IPR meant that international licensing of technology was not really an option until the late nineteenth century. Indeed, many business leaders regarded licensing as an unacceptable strategy right up until the 1980s, and in some cases beyond. Their reasons are related to the issues above. Licensing was very risky because the licensor could not trust the licensee. A licensee could re-sell the technology to others, or invade markets that the licensor had awarded to other people. They could use their experience to improve the technology and then register the new technology as their own. Similar risks applied to consumer brands (Lopes, 2007). Perceived risks varied between countries, e.g. Hong Kong had a very bad reputation, while the Netherlands had a much better one. Where licensing was used, it was often on a cross-party basis; each firm licensed a technology from the other, or partnered them in a patent pool, giving each licensor a sanction against their licensee. 
The IB literature sometimes regards licensing as a purely hypothetical option rather than a realistic one (see above), but the recent strengthening of IPR through international treaty organisations has made it is more realistic than it was before (Ryan, 1998).

Proposition 4. Military technology may generate civilian technology as a spin-off.

A technology may have multiple applications. A military technology may be defined as a technology developed for military use and refined as a result of experience in war, while a civilian technology is designed for use in peace and improved in the light of production experience and customer response. Civilian technologies can be used by a military power to strengthen, not only its own economy, but the economies of other countries that it controls. While military technology can generate civilian spin-offs, the converse also applies: civilian technologies may have important military uses.

Transport and communications technologies are particularly significant in this respect. Aircraft, for example, were developed for military purposes during two world wars, but their major impact has been in civilian use: promoting international business travel, international tourism, and most recently, supporting just-in-time supply chains in high-value intermediate products.

Railways illustrate the opposite case. They were developed in the early nineteenth century to carry coal and manufactured goods, and they then diversified into carrying passengers too. They were used in the American War of Independence, 1861-5, and the Franco-Prussian War of 1870, to carry munitions and troops to front-line positions. By the time of World War I, railways had transformed the logistics of war on land (Wolmar, 2009).

It is sometimes difficult to determine which came first: civilian or military use. In the fifteenth and sixteenth centuries, ship-building technology and the science of navigation played a crucial role in both war and peace. Large ships designed to carry heavy guns could be adapted to carry bulk cargoes, and vice versa. They could also sail long distances, across seas rather than just along the coasts, making long-distance trade viable for a wider range of products (Gertwagen and Jeffreys, 2012).

Proposition 5. A combination of military and civilian technologies facilitates the conquest of foreign territories.

Shipping had a crucial impact on colonisation. The gun-power of the large ships made the conquest of territory easier, and especially the capture of major ports. Sailing up-river was more problematic because of the deep draught and the shallow water. Once the port had been captured, the ship could carry away large cargoes of plundered goods. Ships could also be used to export slaves, who were often captured by native tribes and sold to the ship-owners who were keen to satisfy growing foreign demand (Tracy, 1990).

Raiding weaker countries was often a poor substitute for settling them. In the ninth and tenth century Viking raiders encountered diminishing returns to plundering European settlements, and decided that it was more productive to settle on the fertile agricultural instead. Raid was replaced by trade, which elicited co-operation from the local people (Hadley, 2002). While 
the raider's military power may reflect their superior military technology, this technology may be linked to superior civilian technology too. Given that technology at this time was embodied in people rather than in books or plans, settling the country was a useful way of importing civilian technology and putting it to use.

Advances in ship design allowed longer voyages to be made. The Venetian explorer Marco Polo, who 'discovered' China in 1266, travelled overland, but very soon it was possible to reach China by sea. China was strong enough to resist colonisation, but it failed to develop its international trade as a result (Larsen, 1989). Long-distance voyages of exploration funded by Spanish and Portuguese monarchs led to the colonisation of Latin America, and it was not long before the Dutch, the English and other European powers developed colonies even further away (Tracy, 1990).

Proposition 6. Settlement of a conquered foreign territory stimulates infrastructure investment, which in turn encourages FDI in export-oriented production.

There are four main reasons why a powerful nation may wish to extent its control of territory.

Security. It may wish to protect its borders by occupying neighbouring countries. This typically applies to land-locked countries, because island countries have a natural barrier along their coast. Germany after the rise of Bismark in 1871 is a case in point (Morrow, 1943)

Population pressure. Productivity gains from new civilian technologies may increase living standards, reducing infant mortality and accelerating population growth. Conquering lightly populated territory permits mass emigration, and alleviates population pressure on land. UK emigration policy after the repeal of the Corn Laws in 1846 is an example (Wakefield, 1849). The native population in the conquered country may be small, and in some cases may be wiped out by low resistance to new diseases (Cook and Lovell, 1992).

The two other reasons have been mentioned above.

Access to raw materials. These can take various forms; metal ores, such as iron, energy resources such as coal and oil, or soil and climate suitable for agriculture. To secure future supplies of minerals, it may be deemed prudent to acquire the availably stocks outright, rather than by purchase as and when required.

Capture of a market. A powerful country may be concerned about the loss of export markets should new technologies or natural resources be discovered elsewhere. It can secure export demand by locking in consumers through conquest, thereby 'locking out' rival suppliers.

Settlement creates a demand for housing, towns, transport networks, power distribution systems, and so on. It also creates demands for regional and local administration, law and order, medicine, education and sporting and cultural activities. While indigenous people may already have services of this kind, they are unlikely to meet the expectations of settlers from a more powerful, and therefore wealthier, economy. Furthermore, the settlers may wish to display their wealthy conspicuously in order to justify their status (Mosley, 1983). 
This encourages FDI in infrastructure and, as infrastructure improves, it may also encourage FDI in export-oriented production (e.g. New Zealand lamb and butter exports to the UK). Production for export may take place in the context of an empire or a preferential trading area (British Empire, Soviet Union). Given that the settlers are already familiar with home country preferences, exports may well be concentrated on the home country markets. The incentive to trade with the home country may be strengthened further if, as was often the case, the home country offers preferential arrangements (e.g. lower tariffs) to the settler economy (Brooke, Enders and Rogers, 2016).

Domestic infrastructure investment may also facilitate the distribution of imports. If the settlers have a strong preference for home country products then this may further strengthen their ties with the home country. The home country imports consumer products from the home country and exports raw materials or agricultural products to pay for them.

A strong bilateral arrangement of this kind between a home country and a settler economy has both advantages and disadvantages for both parties. The advantage is that each country can count on the other for political and military support. Although the stronger country has more to offer the weaker country in this respect, the stronger country may still benefit if it is threated by another strong country, as was the case in the UK during two World Wars.

A disadvantage is that when a rival country emerges as competing supplier for the home country market, the settler country may find that the home country liberalises its trade arrangements in order to switch to the new supplier. This may leave the settler country in difficulties, because the trade preferences may have disguised underlying problems, such as low productivity and technological obsolescence. This threat became a reality when the UK disengaged from its Commonwealth partners in order to join the European Union (EU); it has now become a threat for the UK itself as it disengages from the EU and seeks to make trade agreements elsewhere.

Proposition 7. Technology transfer from a powerful country to a weaker one risks building up the weaker country into a rival power. There is nothing that can prevent the potential emergence of a rival.

This is a fundamental proposition with very significant policy implications. It is not a new proposition, by any means, but it is somewhat understated in recent debates on IB policy. It has often been assumed, at least implicitly, that private enterprise and free markets are the best way to organise any economy, and that economies that embrace these principles can retain their dominance indefinitely. Historical evidence does not support this view, however. In the seventeenth century Spanish and Portuguese supremacy was undermined by rivalry from the Dutch, in the nineteenth century Dutch Supremacy was undermined the British, and in the twentieth century Britain was surpassed by the US.

Certain features of a leading economy may delay the onset of decline, but there is disagreement about what these features are. Work ethic, respect for authority, equality of incomes, freedom of association and freedom of thought are just a few of the qualities that have been suggested (Lall, 1998; Lynn, 1991). This paper does not engage with this question. 
The proposition is simply that, whatever the characteristics of a leading country, it is always under threat.

According to internalisation theory, an important motive for outward FDI is to maintain control of a technology used in overseas production. It is postulated that FDI is more secure than alternative contractual modes such as licensing. But there are risks even with FDI. Historical evidence suggests that even with patent protection and the security of FDI, loss of leadership is possible. This applies to the individual firm, and to the nation state as well.

To elaborate on this point it is useful is distinguish two types of knowledge: strategic knowledge, which is knowledge of an entire production system and how it needs to be configured, and instrumental knowledge, which is more specialised technical knowledge about how one element of the system works. It is relatively easy for someone with strategic knowledge to identify individuals with appropriate instrumental knowledge, but more difficult for a person with instrumental knowledge of a single element to acquire strategic knowledge of the system. Strategic knowledge is key to radical innovation, particularly where international supply chains are involved. It indicates how a supply chain is to be configured and the most appropriate method of coordination (e.g. subcontracting or FDI).

Strategic knowledge is very scarce, and is possessed by highly talented people, while instrumental knowledge is also scarce, but to a lesser degree. Strategic knowledge confers military and economic strength on the country, but instrumental knowledge merely equips a country to participate in supply chains designed and organised by more powerful countries. UK military power in the nineteen the century stemmed strategic technologies for steampowered transport by rail and sea. Germany power in the early twentieth century stemmed from strategic knowledge in steel and chemicals, while US power in the mid-twentieth century stemmed from strategic knowledge of the mass production methods for durable consumer goods. US power has extended into the twenty-first century through strategic knowledge of computing and the internet (Bauer and Latzer, 2016).

The change of leadership from the UK to Germany to the US illustrates the difficulty for any nation of retaining strategic leadership in a technology for very long. As a technology matures, leading countries tend to get locked in, by focusing on incremental improvements that perfect the existing technology (see e.g. David, 1985). These incremental improvements generate decreasing returns to research effort, and distract attention from new more radical opportunities that are opened up.

Strong nations have several ways in which they can mitigate the risk of catch up, but none of them is particularly effective. For example, they can restrict the type of knowledge transferred abroad; this method is used to protect state secrets, but is very expensive for a private enterprise to implement. They can also learn from the countries that are learning from them, but this merely prevents them from falling behind, and does not safeguard their leadership.

In the nineteenth and twentieth centuries weaker nations became very adept at catching up (Gerschenkron, 1968). As high-technology products were exported more widely, it became 
easier to reverse-engineer strategic technology by purchasing samples of the product. The globalisation of supply chains disseminated instrumental knowledge widely, and allowed enterprising weaker countries to synthesise this knowledge into strategic knowledge. The growth of university education made it easier for foreign students and researchers to master the scientific underpinnings of strategic knowledge. A rival country could acquire strategic knowledge by pooling the knowledge of returnees (Schmidt, Mansson and Dolles, 2014).

The post-war policy consensus amongst leading Western nations, based on globalisation and world development, has promoted the notion that the diffusion of technologies from strong countries to weaker countries is a win-win situation. Development agencies, funded indirectly by strong countries would improve education, health and institutional quality in weaker countries (Sachs, 2008). Workers in these countries would acquire instrumental technologies that would equip them to participate in global supply chains. They were expected, however, to play only a subordinate role. Profit would be extracted by the supply chain leader, based in a strong country, that possessed a strategic technology created by their highly talented researchers. Implicit in this view was that workers in weaker 'developing' countries would acquire only instrumental technology. As development progressed, it was thought, developing countries would compete against each other for off-shore production, reinforcing the bargaining power of the supply chain leaders. Workers in developing countries would become marginally better off, while talented researchers and investors in the supply chain leaders would become substantially better off.

In practice, however, not all weaker countries have developed as fast as expected. While some have achieved significant improvements in living standards, they are not always much better off in absolute terms because their initial standard of living was so low. Other countries have not developed much at all. This has meant that competition for off-shore production has not been so intense as would otherwise have been the case. This is a benefit to the countries that have developed, a loss to the countries that have not developed, and also a loss to the supply chain leaders who have less market power over their suppliers than they anticipated. Furthermore, there have been major losers amongst some of the strong countries, such as the US, where unemployment as risen as workers whose jobs were offshored have been unable or willing to take jobs elsewhere (Espejo, 2015).

Some weaker countries set out to acquire not only instrumental technologies but strategic ones too. As early as the 1960s Hong Kong was assimilating a range of different technologies at a significant rate. In the 1970s Japan emerged as a major force, taking the lead in the automobile industry. Other 'Asian Tigers' emerged in the 1980s, and in the 1990s there were great hopes for the BRICs. These 'newly industrialising' or 'emerging market' economies developed state-owned multinationals that invested in leading countries with the objective of acquiring strategic technologies and mass-marketing skills (Williamson, 2013).

For most of these countries the results have been mixed. Even where they gained a foothold in foreign markets, or established links with local universities, their foreign investments have not always been profitable. One country stands out as being successful, however. China has acquired strategic technologies from strong Western countries, notably the US, and has 
successfully challenged firms based in these countries, both in their home markets and in third-country markets too.

Proposition 8 . The path to economic power has been broadly the same for all successful countries.

Post-Maoist Chinese strategy has been similar to the technology acquisition strategies of the middle ages, the 'catch up industrialisation strategies' of the nineteenth century, and the FDI strategies of other emerging nations in the twentieth and twenty-first centuries.

Some historical attempts at winning power were successful and some were not. Some successful countries sustained their leadership for longer than others, but all eventually lost it. Those that succeeded and then sustained their leadership pursued their strategies in a sophisticated way. They were good at identifying both opportunities and threats. They identified weaknesses of established rivals that they could exploit to achieve their dominance, and also threats from potential rivals that they needed to deter in order to retain their position for as long as possible.

Some historically powerful countries have enjoyed natural geographical advantages, but no single advantage seems to be crucial. Some leading countries like the UK and Japan are small islands, while Germany, China and the US are large countries that are part of even larger continents. Rivers are key in land-locked countries, but while the US is well-served by rivers, large parts of Germany are reliant on the Rhine, which borders other countries. These countries may have enjoyed advantages derived from social and institutional arrangements but, as noted above, there is no agreement what these are.

China's recent success seems to derive in large part from learning the 'lessons of history' and translating them into modern terms. It has mastered classic forms of state-craft, such as collecting foreign intelligence in a systematic way (Hannas and Mulvenon, 2013). It has used foreign universities as a training ground for its researchers, and encouraged them to gain employment with major foreign firms before returning home. It has secured the raw materials it needs to exploit its new manufacturing technologies from neighbouring countries and from other continents, using both long-term contracts and FDI for this purpose. It has offered cheap loans to governments in developing countries in order to finance their share of these investments. In Africa it has financed and constructed new railways to link inland mines with coastal ports. It has also proposed a 'belt and road' initiative to link China to Europe, the Mediterranean and the Caspian Sea (Buckley, Clegg, Cross, Liu, Voss and Zheng, 2007; Yueh, 2016).

These strategies are remarkable similar to those of British governments in the Age of High Imperialism, 1870-1914. British embassies collected commercial intelligence from embassies across the world, and then circulated the reports to relevant ministers that in turn contacted leading forms to alert them of emerging business opportunities. It encouraged prospectors and speculators from across the world to float companies in the London capital market. Many railways, both inside and outside the British Empire, were financed in this way. They were 
often built by British civil engineers working with British contractors supervising local gangmasters who recruited local labour (Boughey, 2009).

Many modern Chinese strategies resemble the strategies of UK imperialism. There are differences in implementation, however. Perhaps that most important is that Chinese FDI relies heavily in state finance, whereas the UK relied on private finance. Some commentators regard this as a vital weakness in the Chinese strategy, but only time will tell. It is difficult to assess the long-term financial returns from British strategy because most of the early FDI was divested to pay back the loans taken out to finance two World Wars. Similarly it is difficult to assess the financial returns to China until the extent of loan defaults becomes clear.

The real question, it might be said, is why China is the only country that has succeeded in challenging Western leadership, rather than why it has managed to do it at all. Since the end of World War II Western industrial policies have implicitly assumed that Western supremacy is a given, The West has ignored the fact that leadership has moved between countries in the West, that such movement has always proved hard to resist and that there is no reason, in principle, why leadership, when it changes, has to pass to another Western country.

There are other countries that can learn the true 'lessons of history' by studying the Chinese experience. India is a case in point. Like China, it has a large territory, a large population and good supplies of coal. Furthermore, its legacy of colonisation gives it good ports, an extensive railway system and a good awareness of English language and Western culture. It is, however, a country with many different regional cultures, some of which, it is alleged, value social status rather than business achievement (Lall, 1998). It is possible that it has been two preoccupied with managing long-standing internal conflicts to take full advantage of new external opportunities.

\section{FDI and imperialism: its relevance today}

Since the end of World War II the US has been the dominant global power. This raises the controversial question of whether the US can be viewed as a modern imperial power. US politicians deny this, but their critics disagree (Wallerstein, 2004, 2013). For historical reasons, the US perceives the UK as an imperialist, and itself as a victim of imperialism in the past. The US, it is said, decisively rejected British imperialism in 1776, and has denounced imperialism in general ever since.

There are, however, different forms of imperialism: formal imperialism, such as British control of the West Indies, or informal imperialism, such as British influence in Argentina, are both are linked to FDI (Casson, Dark and Gulamhussen, 2009). The US may not have been a formal imperialist, but informal imperialism is a more difficult accusation to refute.

From the 1920s onwards, it could be said, the US acted as an informal imperialist in different parts of the world, in pursuit of oil, tropical products, cheap labour and captive export markets. The locations include South-east Asia, Latin America and the Middle East. The US acquired not only an economic presence but a military presence too, giving it control, not only of the Atlantic, but the Gulf and the Pacific too. 
Indeed, it was allegations of US imperialism in post-war Europe that indirectly gave rise to modern IB theory. After World War II labour was in short supply in the US, and transatlantic transport costs were high. Europe was a cheap-labour location in which to produce US products for the European market (Vernon, 1966, 1970). The US occupied part of Germany and funded much of European reconstruction though its generous Marshall Plan. The repatriation of profit from US European subsidiaries became a political issue, however. Political radicals on both sides of the Atlantic took a critical view of profit repatriation, especially when viewed from a Marxist perspective (Rowthorn and Hymer, 1971).

Modern IB theory reconciled, to some degree, opposing political views on this issue. The profit was a payment for the use of intellectual property created in the US. It was a win-win situation. The US specialised in developing civilian technology and Europe specialised in manufacturing production. So long as Europe stuck to instrumental technology, the US could monopolise the strategic technology and extract its profit accordingly.

This analysis became a key component of the 'Washington consensus' - a global policy stance that embraced wider global issues . At the end of World War II the economic development of poorer countries also became, by default, a US responsibility, and the Washington-based World Bank was established for this purpose. From a US perspective, what worked for Europe could work for developing countries too. Indeed, war-torn Europe resembled, to some extent, a 're-developing' country.

Poor countries were encouraged to invest in education, health and good government, and to master instrumental technologies. This would allow them to attract off-shore FDI. Powerful countries such as the US would continue to control strategic technologies, however. This policy agenda secured domestic markets and domestic resources in weaker countries for US exports and FDI.

This policy stance appears to have given the US a false sense of security. Their political leaders assumed that continued dominance was guaranteed. Since then the US has faced successive threats to its dominance in high-technology manufacturing from Japan, Korea, and Germany, and has survived only by ceding global market share to these rivals. There were also potential threats from the BRICS, but these have mostly failed to materialise, mainly because of internal political problems. Sooner or later one of these countries - specifically China - had to succeed. Its success cannot be questioned, but the final outcome still remains uncertain.

Many US policy-makers have taken the ideological view that no economy that failed to fit the democratic capitalist model could ever succeed in challenging one that did (Fukuyama, 1992) The US witnessed the implosion of the Soviet Union in the 1980s, and it was only a matter of time, it was believed, before something similar would occur in China. Disturbances in Hong Kong, and social tensions fuelled by the corona virus, could well precipitate a crisis, and a possible end to Communist Party control. Even if they are right, however, the collapse of the Communist party might not be the end of the challenge from China, and even if it were, there will be India, or some other country, to contend with later, as noted above. 


\section{Conclusion: the national dimension of FDI}

This paper has offered a 'big picture' view of how IB has evolved over time, with a focus on the interplay of the MNE and the nation state. The nation state is important to IB because it is the defining unit, without which there would be no IB to study. Global business would still exist in a politically unified world, but IB, by definition, would not.

Given the importance of the nation sate, it is surprising that it has not figured more prominently in IB theory. The nation state is relatively passive in most accounts of the theory; differences between states create 'liability of foreignness' (Zaheer, 1995) and 'costs of doing business abroad' (Hymer, 1976). When the nation state plays an active role in the IB arena, its impact is generally perceived as negative, e.g. protectionist policies lead to trade barriers whilst military threats lead to war.

But historical evidence shows that the role of the state has been crucial is developing strategic technologies. The state can fund military R\&D that has civilian spin-offs, and promote infrastructure mega-projects to encourage learning by doing. It can head-hunt talented workers from overseas. Its military power can secure access to key resources overseas. Its control of the oceans and the skies can secure international transport and communications, and contribute to cyber-security.

The key point to emerge from this study, therefore, is that there is competition between nations and well as competition between firms. These two forms of competition interact. Nations use their leading firms as instruments of international policy. Conversely, leading firms rely on political and financial support from their home nations. It is the interplay of firm and nation state that has driven the evolution of IB over the last eight hundred years.

This study has used economic history to generate a robust evidence base, from which eight key propositions have been derived. These propositions highlight the interdependence of FDI and trade; the connection between the conquest of territory and the exploitation of natural resources; and unscrupulous nature of international rivalry for the acquisition of technology.

The clear message is that IB theory needs to strengthen its political dimension and to pay more attention to the way that political strategies and business strategies interact. The evidence shows that the nation states of progressive countries have always taken a strong interest in international trade and FDI. For the enterprising state, military policy, foreign policy and economic policy are much more closely connected than conventional IB theory suggests. 


\section{References}

Bauer, Johannes M. and Michael Latzer (eds.) (2016) Handbook on the Economics of the Internet, Cheltenham: Edward Elgar

Baumol, W. J., Mokyr, J., and Landes, D. S. (eds.) (2010) The Invention of Enterprise. Princeton, NJ: Princeton University Press.

Beckert, Sven (2014) Empire of Cotton: A Global History, New York: Alfred A.Knopf Bernholz, Peter and Roland Vaubel (eds.) (2004) Political Competition, Innovation and Growth in the History of Asian Civilizations, Cheltenham: Edward Elgar

Boughey, David (2009) British overseas railways as free-standing companies, 1900-1915, Business History, 51(3), 484-500

Brooke, Geoffrey, Anthony Enders and Alan Rogers (2016) Does New Zealand economy have a useful past? The example of trade policy and economic development, New Zealand Economic Papers, 50(3), 281-302

Buckley, Peter J. and Mark Casson (1976) The Future of the Multinational Enterprise, London: Macmillan

Buckley, Peter J. and Mark Casson (1998) Analyzing foreign market entry strategies: Extending the internalization approach, Journal of International Business Studies, 29 (3), 539-562.

Buckley, Peter J., Jeremy Clegg, Adam R.Cross, Xin Liu, Heinrich Voss and Ping Zheng (2007) The determinants of Chinese outward foreign direct investment, Journal of International Business Studies, 38(4), 499-518

Casson, M. (2018). The Multinational Enterprise: Theory and History. Cheltenham: Edward Elgar.

Casson, Mark (2019) The making of global business in long run perspective, in: Lopes, Teresa da Silva, Christina Lubinski, and Heidi Tworek, (eds.) The Routledge Companion to the Makers of Global Business. Routledge, Abingdon, UK, pp. 35-54. ISBN 9781138242654

Casson, Mark and Catherine Casson, eds. (2013) History of Entrepreneurship: Innovation and Risk-taking, 1200-2000. Cheltenham: Edward Elgar, Cheltenham, pp1608. ISBN 9781781955239

Casson, Mark, Kenneth Dark and Mohamed Azzim Gulamhussen (2009) Extending internalisaton theory: from the multinational enterprise to the knowledge-based empire. International Business Review, 18 (3). pp. 236-256. ISSN 0969-5931 doi: https://doi.org/10.1016/j.ibusrev.2008.12.005 
Cook, Noble David, and George W. Lovell (1992) 'Secret judgements of God': Old World Disease in Colonial Spanish America, Norman: University of Oklahoma Press

Cools, H., M. Keblurek and B. Nolaus (2006). Your Humble Servant: Agents in Early Modern Europe. Hilversum: Uitgeverij Verloren.

Cunningham, William (1897). Alien immigrants to England. London: Swan Sonnenschein.

David, Paul A. (1989) Clio and the economics of QWERTY, American Economic Review, Papers and Proceedings, 75(2), 332-7.

Dollinger, P. (1970). The German Hansa. London: Macmillan.

Dunning, John H. (1983) Changes in the level and structure of international production: the last one hundred years, in Casson, Mark (ed.) The Growth of International Business, London: Allen \& Unwin, 84-139

Dunning, John H. and Sarianna M. Lundan (2008)Multinational Enterprises and the Global Economy, $2^{\text {nd }}$. ed., Cheltenham: Edward Elgar

Espejo, Roman (ed.) (2015) What are the Jobs of the Future? Farmington Hills, MI:

Greenhaven Press

Ferrier, Ronald W. and James H. Bamberg (1982-2000) The History of the British Petroleum Company, 3 vols, Cambridge: Cambridge University Press

Fialka, John J. (1997) War by Other Means: Economic Espionage in America, New York: W.W.Norton

Fitton, R.S. (1989) The Arkwrights: Spinners of Fortune, Manchester: Manchester University Press

Fukuyama, Francis (1992) The End of History and the Last Man, London: Hamish Hamilton

Gerschenkron, Alexander (1968) Continuity in History and Other Essays, Cambridge, MA:

Belknap Press of Harvard University Press

Gertwagen, Ruth and Elizabeth Jeffreys (eds.) (2012) Shipping, Trade and the Crusade in the Medieval Mediterranean: Studies in honour of John Pryor, Farnham, Surrey: Ashgate

Hadley, D.M. (2002) Viking and native: Re-thinking identity in the Danelaw, Early Modern Europe, 11(1), 45-70

Hannas, William C. and James C. Mulvenon (2013) Chinese Industrial Espionage:

Technology Acquisition and Military Modernization, New York: Routledge

Hertner, Peter and Geoffrey Jones (eds) (1986) Multinationals: Theory and History, Aldershot, Hants: Gower Press 
Horton, John, William R. Kent and Christopher Stanton (2017) Digital Labour Markets and Global Talent Flows, Cambridge, MA: National Bureau for Economic Research

Hunt, E. S. (1994). The Medieval Super-companies. Cambridge: Cambridge University Press. Hymer, Stephen H. (1976) The National Operations of International Firms, Cambridge, MA: MIT Press

Jones, Eric L. (2003) The European Miracle, 3rd.ed., Cambridge: Cambridge University Press

Jones, Geffrey (2002) Merchants to Multinationals, Oxford: Oxford University Press

Jones, Geoffrey (2005) Multinationals and Global Capitalism: From the Nineteenth to the Twenty-first Century, Oxford: Oxford University Press

Karsten, L. (2013). Globalisation and Time. Abingdon: Routledge.

Kennedy, P. (1987). The Rise and Fall of Great Powers. New York: Random House.

Kotkin, Stephen (2003) Armageddon Averted: The Soviet Collapse, 1970-2000, Oxford:

Oxford University Press

Lall, Deepak (1998) Unintended Consequences, Cambridge, MA: MIT Press

Larsen, Jeanne (1989) Silk Road, London: Heinemann

Lewis, D., and K. Moore (1999). Birth of the Multinational. Copenhagen: Copenhagen Business School Press.

Li, Shaomin and Ilan Alon (2020) Chinese intellectual property rights provocation: A political economy view. Journal of International Business Policy, 3, 60-72

Lockhart, James and Stuart B. Schwartz (1983) Early Latin America: A History of Colonial Spanish America and Brazil, Cambridge: Cambridge University Press

Lopes, Teresa da Silva (2007) Global Brands: The Evolution of Multinationals in Alcoholic Beverages, Cambridge: Cambridge University press

Lopes, Teresa da Silva, Mark Casson and Geoffrey Jones (2019) Organizational innovation in the multinational enterprise: internalization theory and business history. Journal of International Business Studies, 50 (8). pp. 1338-1358. ISSN 1478-6990 doi: https://doi.org/10.1057/s41267-018-0156-6

Luu, Lien (2005) Immigrants and the Industries of London, 1500-1700, Aldershot, Hants: Ashgate

Lynn, Richard (1991) The Secret of the Miracle Economy, London: Social Affairs Unit Morrow, Ian F.D. (1943) Bismark: London: Duckworth 
Mosley, Paul A. (1983) The Settler Economies: Studies in the Economic History of Kenya and Southern Rhodesia, 1900-1963, Cambridge: Cambridge University Press

Mukhopadhyay, Aparajita (2018) Imperial Technology and 'Native' Agency: A Social History of Railways in Colonial India, 1850-1920, Milton, Oxon: Routledge

Narula, Rajneesh (2003) Globalisation and Technology: Interdependence, Innovation Systems and Industrial Policy, Oxford: Polity Press

Olmstead, Alan L. and Paul W. Roade (2018) Cotton, slavery and the new history of capitalism, Explorations in Economic History, 67, 1-17

Ormrod, Mark, McDonald, N. and Taylor, C. (eds.) (2018). Resident Aliens in Late Medieval England. Turnhout: Brepols.

Pedler, Frederick (1974) The Lion and the Unicorn in Africa: A History of the Origins of the United Africa Company, 1787-1931, London: Heinemann

Ramirez, Miguel D. (2006) Is foreign direct investment beneficial for Mexico? An empirical analysis. World Development, 34(5), 802-817

Rogers, Clifford J. (2010) The Oxford Encyclopedia of Medieval Warfare and Military Technology, Oxford: Oxford University Press

Rowthorn, Robert and Stephen H. Hymer (1971) International Big Business, 1957-67: A Study of Comparative Growth, Cambridge: Cambridge University Press

Ryan, Michael P. (1998) Knowledge Diplomacy: Global Competition and the Politics of Intellectual Property Rights, Washington, DC: Brookings Institution

Sachs, Geoffrey D. (2008) Common Wealth, New York: Penguin Press

Schaffer, Simon (1995) The show that never ends: Perpetual motion in the early eighteenth century, British Journal of the History of Science, 28(2), 157-189

Schumpeter, Joseph A. (1934). The Theory of Economic Development. (Trans. R.Opie). Cambridge, MA: Harvard University Press.

Schmidt, Christian, Sebastian Mansson and Harald Dolles (2014) The new face oif talent management in multinational corporations, in Alvestam, Claes G., Harald Dolles and Patrik Strom, Asian Inward and Outward FDI: New Challenges in the Global Economy, Basingstoke, Hants: Palgrave Macmillan, 87-114

Strange, Susan (1988) States and Markets, London: Frances Pinter

Tracy, James D. (ed.) (1990) The Rise of Merchant Empires: Long-distance Trade in the Early Modern World, 1350-1750, Cambridge: Cambridge University Press

UK government (2020) https://www.gov.uk/government/statistics/companies-registeractivities-statistical-release-2018-to-2019, accessed 16/05.2020 
Verbeke, Alain (2013). International Business Strategy, $2^{\text {nd }}$. ed., Cambridge: Cambridge University Press.

Vernon, Raymond (1966) International investment and international trade in the product cycle, Quarterly Journal of Economics, 80(2), 190-207

Vernon, Raymond (1970) Sovereignty at Bay. New York: Basic Books

Wakefield, Edward Gibbon (1849) A View of the Art of Colonization, London: S.W.Parker.

Wallerstein, Immanuel M. (2004) World Systems Analysis: An Introduction, Durham, NC:

Duke University Press

Wallerstein, Immanuel M. (2013) Does Capitalism have a Future? New York: Oxford University Press

Wilkins, Mira and Harm Schroter (eds.) (1998) The Free-standing Company in the World Economy, 1830-1996, Oxford: Oxford University Press

Williams, Eric E. (1966) British Historians and the West Indies, London: Andre Deutsch

Williamson, P. J. (2013). The Competitive Advantages of Emerging Market Multinationals. Cambridge: Cambridge University Press.

Wilson, John F. (1995) British Business History, 1720-1994, Manchester: Manchester University Press

Wolmar, Christian (2009) Blood, Iron \& Gold: How the Railways Transformed the World, London: Atlantic Books

Yamamoto, Koji (2018) Taming Capitalism before its Triumph: Public Service, Distrust and 'Projecting' in Early Modern England, Oxford: Oxford University Press

Yueh, Linda (2016) Globalisation and growth: the case of China, in Marek Belka, Ewald Nowotny, Pawal Samecki and Doris Ritzberger-Grunwald (eds.), Boosting European Competitiveness: The Role of the CESEE Countries, Cheltenham: Edward Elgar, 48-57

Zaheer, Srilata (1995) Overcoming the liability of foreignness, Academy of Management Journal, 38(2), 341-63 


\section{Acknowledgements}

I am grateful to Teresa da Silva Lopes for discussions on this topic and to Danny Shapiro and Janet Casson for comments on a preliminary version of this paper. 